A practical academic reading and vocabulary screening test as a predictor of achievement in first-year university students: implications for test purpose and use

Jordi Heeren $^{\text {ab }}$, Dirk Speelman ${ }^{\mathrm{a}}$, Lieve De Wachter ${ }^{\mathrm{b}}$

${ }^{a}$ Faculty of Arts, KU Leuven, Leuven, Belgium, ${ }^{b}$ Leuven Language Institute, KU Leuven, Leuven, Belgium

Dekenstraat 6, 3000 Leuven, Belgium. jordi.heeren@kuleuven.be, ORCID iD:

https://orcid.org/0000-0002-4412-5206

word count: 6262 


\title{
A practical academic reading and vocabulary screening test as a predictor of achievement in first-year university students: implications for test purpose and use
}

\author{
Language proficiency is assumed to play a role in achievement in tertiary \\ education. When requirements for university entrance are low or demographic \\ changes in the population take place, universities often employ post-admission \\ language assessments to screen all incoming students. In this study, we will look \\ at the predictive validity of a practical, low-stakes, web-based academic reading \\ and vocabulary screening test. Additionally, we will investigate the predictive \\ value of the screening test when other known predictors are controlled for. Our \\ results confirm prior research that academic language proficiency is a small but \\ meaningful predictor of achievement in that it can detect the students that are at- \\ risk because of lower language proficiency. The result correlates modestly with \\ our measure of achievement, credit completion rate, with a correlation coefficient \\ of around .30. When other predictors are controlled for in a multiple regression \\ analysis, demographic background variables do not seem to have a large impact \\ on the predictive value of the language screening test. In our sample of mostly \\ native speaking monolingual students, the academic language proficiency \\ measure does appear to reflect students' educational background variables. As a \\ low-stakes instrument, it is useful as an early-alert signal, prompting further \\ diagnosis or remedial activities.
}

Keywords: predictive validity, academic reading, vocabulary knowledge, academic achievement, first year students

\section{Introduction}

Language tests are often used to test the language proficiency in international L2 students enrolling in tertiary education based on the claim that a certain level of proficiency is needed to be able to cope with the language demands in the study setting (McNamara \& Ryan, 2011). While most studies focus on international students, some studies suggest that L1 speakers scoring below a certain proficiency threshold may be at a greater risk of failing in their first year at university as well (De Wachter, Heeren, 
Marx, \& Huyghe, 2013; Elder, Bright, \& Bennet, 2007; Van Dyk, 2015). In their review study, Hamilton et al. (1993) found that although native speakers outperform L2 students on high-stakes academic language tests their performance 'is far from uniform and is significantly related to educational level and work experience' (Hamilton et al. 1993, 346). In university systems with lower entry requirements, L1 students from low literacy backgrounds or from secondary school tracks with limited language demands may also face language challenges (Elder, 2017; van Kalsbeek \& Kuiken, 2014). In Flanders, where universities do not have admission requirements for students who graduated from Flemish secondary education, except for Dentistry and Medicine, the growing inflow of students led to an increase in the diversity of students' backgrounds (Glorieux, Laurijssen, \& Sobczyk, 2014). Research by Deygers, Peters and Van Den Branden (2017) suggests that the assumption that students who graduated from Flemish secondary schools have adequate language skills to start university studies might not always hold true.

In response to low(ered) university entrance requirements or demographic changes in the incoming domestic student population, universities often employ locally developed post-admission language assessments (De Wachter \& Heeren, 2013; De Wachter, Heeren, Marx, \& Huyghe, 2013; Elder, 2017; Read, 2015; Read, 2016; Van Dyk, 2015). These tests measure the language proficiency of all incoming students and 'are used not for selection but as a mechanism for determining who might benefit from additional language development opportunities' (Knoch \& Elder, 2013, 60). The construct of these post-admission language tests typically focuses on 'academic language proficiency' or 'academic literacy' (Read, 2015; Read, 2016; van Dyk, 2015). This study investigates the usefulness of a locally developed, practical academic 
language screening test testing academic reading ability and academic vocabulary knowledge in identifying at-risk first-year students at the KU Leuven.

\section{Academic language proficiency as a construct}

Although the term 'academic language' has found its way into mainstream education, it has no single, clear definition (Baker \& Wright, 2017). As with many constructs in tests that test language for specific purposes (LSP), it is hard to define the construct theoretically. In addition, the more academic language is defined as discipline specific, the more problematic the role of, for example, content knowledge becomes (Davies, 2001). In reality, language demands vary across the disciplines, topics, languages and modes (Fløttum, Dahl, \& Kinn, 2006). However, certain common characteristics can be distinguished (Snow, 2010; Hyland, 2006). General features of academic language that are often mentioned are non-frequent vocabulary, high lexical density, complex grammatical structures, impersonal language, and sometimes implicit relations between text parts (Hyland, 2006; Van den Branden, 2010). Snow (2010) explains that academic discourse is lexically and grammatically complex because it aims to reduce redundancy and presents information in a concise and precise manner. This is reflected in a high density of information-bearing words and grammatical structures that translate complex ideas into a limited number of words (Snow, 2010).

Academic language is considered to be challenging for all incoming students, including domestic students (Crossman, 2018; Elder, 2017; Wingate, 2015). Theoretically, this aligns with one of the hypotheses following from Hulstijn's BLC/HLC theory. He distinguishes between Basic Language Cognition (BLC), the language skills used in everyday oral conversation, and Higher or Extended Language Cognition (HLC), i.e. the lexically, syntactically and cognitively more complex language, both oral and written, that is also found in (higher) education (Hulstijn, 2015). 
HLC contains low-frequency lexical items and uncommon morpho-syntactic structures in grammatically and lexically complex texts. One of Hulstijn's corollaries is that while all native speakers will perform similarly on BLC-tasks, they will differ substantially on HLC-tasks (Hulstijn, 2015).

In this study, academic language proficiency will be operationalised by an academic reading and vocabulary screening test, henceforth ARV screening test. Reading ability and vocabulary knowledge are closely related, with vocabulary being a strong predictor of reading comprehension ability (Alderson, 2000; Qian, 2002; Read, 2015). In their needs analysis, Berckmoes and Rombouts (2009) stress the importance of vocabulary knowledge in the first year of university education in Flanders. According to university lecturers, students not only need a solid vocabulary base, they should also be able to add new and complex words to their vocabulary repertoire (Berckmoes \& Rombouts, 2009). Vocabulary expansion is considered a priority area in academic reading, and according to Read $(2015,152)$, 'competence in academic vocabulary reflects students' academic literacy in a broad sense and has potential as the basis for efficient diagnostic measures where assessment of students is required across a range of disciplines'. Differences in vocabulary size also seem related with academic achievement (Graham, 1987; Milton \& Treffers-Daller, 2013), and vocabulary knowledge is considered an important element in the transition from secondary to tertiary education (Crossman, 2018).

Reading is also seen as a crucial linguistic skill in university education and international studies have indicated that native speakers' performance on academic reading tests shows substantial variation (Elder, Bright, \& Bennet, 2007; Hamilton et al., 1993; Stricker, 2004). Van Houtven, Peters, and El Morabit (2010) investigated the reading proficiency of 176 college students in Flanders from different disciplines and 
showed that, while first-year students were good at retrieving exact information from a text, they struggled with higher-order reading skills such as interpreting links between texts, grasping the main point, and gaining a detailed understanding of a text (Van Houtven, Peters, and El Morabit, 2010). In addition to these findings, needs analyses reveal that many domestic first-year students struggle with the heavy reading load in higher education (Berckmoes \& Rombouts, 2009; Van Houtven, Peters, \& Van den Branden, 2013). Berckmoes and Rombouts (2009) add that students' reading is not always visible to academic staff since it is mostly done independently. They emphasize that students should use appropriate reading strategies, and have a certain level of speed in doing so (Berckmoes \& Rombouts, 2009, 28). The latter is also stressed by Alderson $(2000,182)$ who states that 'time spent on such [academic reading] tasks [...] is typically perceived as speeded - i.e. under considerable time pressure, working against tight deadlines'. Reading is also shown to be related to achievement, both in groups containing a substantial number of L1 students (Elder, Bright, \& Bennet, 2007) and in L2 students (Dooey \& Oliver, 2002).

The results of the different needs analyses clearly show that commencing students perceive the language in higher education as a challenge. Based on Hulstijn's corollary that domestic students will perform differently on HLC tasks and that students with a low academic language proficiency, similar to L2 students, might be at-risk, the following research questions guided this study:

(1) Is there a correlation between the results on the ARV screening test and academic achievement in the first year of university education?

(2) Can the ARV screening test identify an at-risk group of students?

(3) What is the predictive value of the ARV screening test, when personal and educational background variables are controlled for? 


\section{Materials and methods}

\section{Academic reading and vocabulary screening test}

To measure incoming students' academic reading and vocabulary proficiency, several KU Leuven faculties use the ARV screening test at the start of the academic year. This test was developed in 2009 and was not designed to function as a diagnostic instrument, i.e. to give students a detailed overview of what they know and do not know in a language, but as a practical screening test (De Wachter \& Heeren, 2013). Contrary to high stakes language assessments, that for validity reasons and on washback grounds use more time-consuming integrated task-based measures, more indirect measures are typically used for screening purposes because it is usually more low-stakes and has to be administered to large volumes of students without being too resource intensive (Elder \& van Randow, 2008; Read, 2015). The screening test in this study is web-based, so no software is necessary to administer the instrument. In addition, no raters and consequently no time delays are required to determine test scores: results are automatically calculated by the system and students immediately receive their result after finishing the screening test.

Although it is designed to be a practical instrument with mostly selected response items, we wanted the underlying construct to be broad enough, combining different aspects of reading ability and vocabulary knowledge through different task types with a time constraint of 30 minutes. The construct does not only comprise language knowledge, but also addresses students' strategic competence (Bachman \& Palmer, 1996; Bachman \& Palmer, 2010). Table 1 gives an overview of all item types and tasks included in the screening test construct.

Table 1. 
To achieve authenticity and limit the effect of background knowledge, a sample of short texts and contexts was selected from different disciplines (Alderson, 2000). These include passages of no more than 300 words from course notes, scientific articles, and newspaper articles considered representative of the academic language a first-year student might encounter. While the passages were selected from different disciplines, care was taken to ensure they were not too discipline-specific or technical. Task content was decided on the basis of a needs analysis and then assessed by a steering committee of subject area experts who judged items on their relevance, content, and generic nature (De Wachter \& Cuppens, 2010; De Wachter \& Heeren, 2013). As an additional criterion, all texts were screened using the Flesh-Douma reading ease formula. This formula is an adaptation of the Flesch reading ease formula, developed in order to give a better estimate of the complexity of texts in Dutch (Douma, 1960; Flesch, 1948). Word frequency of the vocabulary items was analysed with the Interactive Language Toolbox which uses combined data from four corpora, namely (1) the corpora provided by the Dutch Human Language Technology Agency (TST), (2) an academic word list based on a corpus of course notes provided by university publisher Acco, (3) the academic word list compiled by Giezenaar and Schouten (2002), and (4) a list of Latin expressions (Verlinde \& Peeters, 2012). The tool classifies words into seven frequency bands and the vocabulary items focused on general academic words from the lowest frequency band.

The ARV screening test, developed and piloted in 2009, has been in use since September 2010 and is available to all KU Leuven faculties. Participation implies that the test is administered in a controlled environment, i.e. an on-campus computer class with supervision. On completion of the test, students immediately receive their results. In addition, faculties can provide their students with a feedback message of their 
choosing. Since the start of the implementation, slightly different versions of the test have been used, all with the same time limit of 30 minutes. Table 2 gives an overview of the number item types and the total number of items per test version. Items that appeared to be too easy were removed in later test administrations.

Table 2.

To determine reliability measures and descriptive analyses all students that were not in their first year for the first time were removed, resulting in a data file containing 12,647 first-year students. Analyses were performed with the psych package in the statistical software $R$ (Revelle, 2018). Table 3 summarizes the descriptive data for each academic year and each test version. The mean ARV screening test score ranged from a minimum of $64.7 \%$ to a maximum of $71.3 \%$, with standard deviations ranging from 12.90 to 14.86 . Time-out refers to the number of students that did not complete the test because they ran out of time. Cronbach's alpha was calculated as a measure of reliability; in addition, test-retest reliability was investigated as a complementary reliability measure in 2010, 2015 and 2016.

Table 3.

Reliability statistics show a moderate internal consistency measured by means of Cronbach's alpha, which is not surprising considering that the construct is broad, the number of different items types relatively large, and the number of items relatively small. When the time pressure increases and a larger number of students were unable to finish the screening test, the internal consistency drops from $0.70-0.68$ to as low as 0.59 . Test speed is indeed a psychometrical issue and may lead to an underestimation of a test's reliability (Alderson, 2000; Hughes, 2003 as quoted in Weir, 2005). Three small scale studies of test-retest reliability were carried out in $2010(n=15)$ with version 1.1, in 2015 (n=30) with version 3.1 and $2016(n=30)$ with version 3.2. In 2016, seven items 
were replaced with new items during the first administration and the original screening test version 3.2 was administered during the second administration. In each study, the amount of time between the first and second administration was 1 to 4 weeks; the resulting correlations were $.75, .77$ and .74 . With the broad construct and the speed effect in mind, these reliability measures were considered sufficient for the low-stakes purpose and use.

\section{Data and methods}

To investigate the ARV screening test's functionality, all test data were linked with students' background variables and study results of the first year. The background data and exam results of 15,032 students were retrieved and anonymized by the university's data management department. A further step was that only students that took their exam in a faculty that had more than 50 students in a given academic year were retained. This way we made sure that there were a sufficient number of students in each faculty to determine meaningful correlation coefficients with study results. Part-time students who took up less than half of their study credits were removed, so that they would not negatively affect the representativeness of the correlations. A student who takes up only one or two courses and passes can clearly not be compared to the overall results of students who take up all of their courses. This resulted in a dataset of 12,435 students. The overview of the resulting number of students in the final dataset used per faculty can be found in Table 4. Some faculties did not administer the screening test in certain years, explaining the empty cells in the table. The faculty of Economics, for example, only participated in 2010, 2012 and 2017. The data consisted of 5196 male students and 7239 female students; 11,978 students had a Belgian nationality and 10,812 indicated that Dutch was their only home language. The average age was 18.26 with a standard 
deviation of 1.316. These descriptive data indicate that the majority of commencing students are 18 year old, monolingual native speakers.

Table 4.

The measure of academic achievement that will be used in this study is students' Credit Completion Rate (CCR). This is the number of credits students enrolled for in proportion to the number of credits that they actually obtained as a percentage. For example, if a student at the end of the first year obtains 54 out of a total of 60 credits, that student's CCR is $54 / 60$ or $90 \%$. CCR takes the weight and importance of each course into account: passing or failing a course which bears more credits will weigh heavier on the overall CCR percentage. It is also a measure used by the university to determine whether students can continue their study or not (KU Leuven, 2018). If students obtain less than $30 \%$ of their credits after the first year, they cannot continue their study; if they obtain less than $50 \%$ but more than $30 \%$ of their credits, they become subject to follow-up measures. We will use CCR after the first semester (CCR in January), the second semester (CCR in June) and at the end of the first year (CCR at the end of the first year) as measures of achievement. First, a correlation coefficient was calculated between the language screening test score and the three CCR measures for each year. Correlations were calculated with IBM SPSS Statistics 24 (IBM Corp., 2018) and the Hmisc package in $R$ (Harrell, 2018).

Second, a multiple regression model was constructed to investigate the predictive value when background variables are added to the model. Regression analyses were carried out in IBM SPSS Statistics 24 (IBM Corp., 2018). For each student, three demographic variables were provided by the data management department, alongside CCR: 'age', 'gender' and 'socio-economic status' (SES). The proxy used to determine SES in this study is the highest degree obtained by one of the 
parents: 'university degree', 'college degree', 'upper secondary education diploma', and 'qualifications lower than upper secondary education'. The variables 'language spoken at home' ('Dutch' and 'not Dutch'), as well as 'nationality' ('Belgian' and 'not Belgian'), were gathered via self-report questionnaires. Research shows that these variables are all related to achievement: females tend to perform better than males, students with a higher SES tend to perform better than students with a lower SES, students who are older usually experienced study delays and tend to perform worse than students who had no delays (Pinxten et al., 2014; Richardson, Abraham, \& Bond, 2012; Lacante et al., 2001).

Track in secondary education and average score in secondary education were also collected by self-report questionnaires. Students' different pre-university education tracks were grouped based on Declerq and Verboven (2010) and Rombaut, Cantillon, and Verbist (2006). There are four major types of secondary education programs in Flanders (Department of Education and Training, 2008). A first type is general secondary education (GSE) providing a broad basis for studies in higher education. Since the majority of students has a GSE-background, they were divided into four categories based on their predictive value (Rombaut, Cantillon, \& Verbist, 2006; Declerq \& Verboven, 2010). GSE1 contains students who combined classical languages with a strong mathematics program. Students in GSE2 have a mathematics and/or science background. GSE3 comprises students that combined a classical language or a science program with modern languages or economics. GSE4 is made up of students who studied economics and languages or social sciences. Due to their small numbers, secondary arts education, technical, and vocational secondary education are considered one group (A/T/VSE). The self-report data on students' educational track was validated by comparing it with the less detailed but authenticated information on students' prior 
educational track found in the university database. When no information was found, the label 'unknown' was administered.

In addition to educational track, high prior achievement is also considered to be a strong predictor of academic success (Richardson, Abraham, \& Bond, 2012; Ting \& Robinson, 1998; Van Dyk, 2015). Given that there are no central examinations in Flanders and students' performance in secondary education is not known to higher education institutions, self-report is the only means of obtaining this information. Prior research into achievement shows that, although there is a possible risk of overestimation, the self-reported performance in secondary education is a powerful predictor of achievement (Lacante et al., 2001; Pinxten et al., 2017; Van Soom \& Donche, 2014). Students reported their average high school score according to the following categories: less than 55\%, 55\%-59\%, 60\%-64\%, 65\%-69\%, 70\%-74\%, 75\%-79\%, 80\%-84\%, 85\%$89 \%, 90 \%-94 \%$ and $95 \%$ or more. Similar to Pinxten et al. (2017), these groups were combined into four groups, since some contained very few students: less than $60 \%$, $60 \%-69 \%, 70 \%-79 \%$ and $80 \%$ or more.

To investigate whether the relation between the screening test results and students' CCR changes over time, Spearman's rank correlations were calculated for three different moments in time. In the multiple regression analysis, we used the ARV screening test as a single predictor in a first step, in a second step we added the background variables 'gender', 'age', 'SES', 'nationality', and 'home language' to the model. Third, we added educational background variables: 'track in secondary education' and 'average score at the end of secondary education'. In the final step, we omitted the ARV screening test result to see its impact on the $R^{2}$ of the final model. The dependent variable 'CCR at the end of the first year' was used in the regression model, 
since it is the measure of achievement the university uses to determine whether students can continue their studies or need follow-up measures.

\section{Results}

\section{Correlation with academic achievement}

For each academic year, the correlation between the ARV screening test and the three measures of achievement was calculated. Since the achievement variables did not approximate a normal distribution, the non-parametric Spearman's rank correlation was used. Table 5 provides an overview of the different correlation coefficients. Table 5.

The correlation coefficients were statistically significant and ranged between .25 and .38. The coefficients do not differ very much between the three different measures of achievement. A number of students seem to be able to improve their CCR after the third exam period in September.

To determine whether the correlation varies in different faculties, we calculated the Spearman's rank correlation coefficients between the ARV screening test and CCR at the end of the first year for each faculty in each academic year. Results can be found in Table 6.

Table 6.

The results show that most correlation coefficients are similar to the general correlations of around .30. There is of course some variation, in the Faculty of Social Sciences in 2016 and the Faculty of Science in 2012 there is a remarkably low correlation of language screening results and students' CCR with a respective correlation of .15 and .19 . In the Faculty of Science there is a remarkably high 
correlation of .38 in 2010. Coefficients in the Faculty of Science are significant, but slightly lower than those in the other faculties.

When we examine the relationship between students' ARV screening test score and their CCR visually, a clearer picture emerges. Since scatterplots with many thousands of students are messy, we divided students into four categories according to their ARV screening test score: 0\%-39\%, 40\%-59\%, 60\%-79\% and 80\%-100\%. Since very few students scored lower than $20 \%$, the lowest scoring group has a wider range. Students were also divided into four groups according to their CCR: (1) students barred from re-enrolment because they failed to complete at least $30 \%$ of their credits; (2) students subject to probationary measures with a CCR between $30 \%$ and $49 \%$; (3) students with average performance and a CCR between 50\% and 79\%; and (4) students who performed above average with a CCR of $80 \%$ and more. Results per test version are depicted in Figure 1 and 2, relating screening test scores with CCR in January, the measure of achievement closest to the ARV screening test, and after year one respectively.

Figure 1.

Figure 2.

Both charts show a fairly linear relation: as the ARV screening test score increases, the percentage of students obtaining less than $30 \%$ and less than $50 \%$ of their credits decreases, while the number of students earning more than half of their credits increases. The picture in both graphs is clearest at the lower end of the scale. In Figure 1 the number of students completing less than half of their credits in the group with the lowest ARV screening test scores ranges from $86.1 \%$ in screening test version 1.1 to $93.5 \%$ in version 2 , and $89.8 \%, 91.1 \%$ and $91.7 \%$ in version $1.2,3.1$ and 3.2 respectively. The percentage of students completing less than $30 \%$ of their credits, and 
by consequence are barred from re-enrolment, ranges between $76.4 \%$ in version 1.1 to $66.7 \%$ in version $1.2,90.3 \%$ in version $2,88.2 \%$ in version 3.1 and $82.4 \%$ in version 3.2. Students with a screening test score from $40 \%$ to $60 \%$ can also be considered at risk: $67.6 \%$ to $81.2 \%$ of students obtain a CCR of less than $50 \%$ in January. Conversely, a high score for the ARV screening test does not guarantee academic success: in January as many as $20.8 \%$ to $31.8 \%$ of the students scoring between $80 \%$ and $100 \%$ on the language screening test complete less than $30 \%$ of their credits. It should be noted that also in the groups obtaining an ARV screening test score lower than $40 \%, 2.8 \%$ to $5.9 \%$ of the students still obtain a CCR of $80 \%$ or more. This might indicate that other variables such as motivation and study aptitude may be crucial as well.

The relation between the two variables is similar after year one, but with a less clearly defined at-risk group, since all groups seem to improve. Nevertheless, the students in the lowest ARV screening test score category can still be defined as at-risk, since the percentage of students completing less than half of their credits is still relatively high: it ranges from $72.2 \%$ in version 1.1 to $69.2 \%$ in version $1.2,87.1 \%$ in version 2 , and $82.4 \%$ and $81.5 \%$ in versions 3.1 and 3.2. The percentage of students completing less than $30 \%$ of their credits ranges between $57.4 \%$ in version $1.1,64.1 \%$ in version $1.2,80.6 \%$ in version $2,70.6 \%$ in version 3.1 and $64.8 \%$ in version 3.2 . In the group of students scoring between $40 \%$ and $60 \%$, the number of students obtaining less than have of their credits has dropped to $50.8 \%$ in version $1.1,52.3 \%$ in version $1.2,49.0 \%$ in version $2,65.4 \%$ in version 3.1 and $65.2 \%$ in version 3.2. These results show that the ARV screening test accomplishes its purpose in that it identifies possible at-risk students. The at-risk group, however, is more clearly defined in January. Students in all language screening test categories improve after year one. These findings 
are similar across screening test versions, suggesting a minimal impact of item changes and changes in time pressure on the relation with achievement.

\section{Regression analysis}

In order to determine the predictive value of the ARV screening test, it is important to investigate its relationship with other known predictors. In a multiple regression analysis, data from 2014 to 2017 were used since average secondary school scores were unavailable prior to 2014 . The model showed no multicollinearity and no distinct indications of violations of homoscedasticity. Two students were excluded from the analysis since the leverage values and Cook's distance were too high. A visual inspection of the P-P plot showed that the residuals approximated normality. The final number of students in the regression was 5165 . We investigated the predictive value of the independent variables separately to ensure that they are all significantly related to achievement at the end of the first year.

A first group of independent variables consists of students' personal background variables: 'gender', 'age', 'SES', 'nationality' and 'home language'. Females $(n=3548$, $M=54.88, S D=37.2)$ performed significantly better than males $(n=1997, M=50.20$, $S D=38.20):(t(4046.86)=4.379 ; p<.001)$, the effect size however is very small $(d=$ 0.12). The Spearman correlation between CCR and age was negative and relatively small, indicating that older students perform slightly worse $(\rho=-.24, p<0.001)$. An analysis of variance indicated that SES was also a significant predictor of achievement $(F(3,5161)=62.299, p<.001)$ with a small effect size $\left(\eta^{2}=0.035\right):$ when at least one of the parents has a university degree, students obtain a higher CCR $(\mathrm{n}=2275, M=$ $60.67, S D=36.37)$ than if at least one of the parents has a college degree $(n=1934, M$ $=52.94, S D=37.26)$, an upper secondary diploma $(n=891, M=42.48, S D=37.1)$ or qualifications lower than upper secondary education $(n=65, M=31.83, S D=34.79)$. A 
post hoc analysis using Hochberg's GT2 indicated that all groups differed significantly, except for the groups of which the highest degree of one of both parents is an upper secondary diploma and lower than upper secondary education. Students with nonBelgian nationality $(n=202, M=39.90, S D=36.65)$ performed significantly worse than Belgian students $(n=5343, M=53.71, S D=37.58):(t(5543)=-5.14 ; p<.001)$ with a medium effect size $(d=0.37)$. Students whose home language is Dutch had a higher CCR $(n=4764, M=55.45, S D=37.41)$ than those with different home language $(n=781, M=39.54, S D=36.11):(t(1073.06)=11,35 ; p<.001)$ with a medium effect $\operatorname{size}(d=0.43)$.

A second group of variables consisted of students' educational background characteristics. In our study, a Welch analysis of variance and games-Howell post-hoc test comparing the mean CCR of the five groups according to educational track showed that all groups differed significantly (Welch's $F(5,1426.2)=218.65, p<.001)$ with a large effect size $\left(\eta^{2}=0.145\right)$. GSE1 $(n=786, M=76.38, S D=31.00)$ scored higher than GSE2 $(n=874, M=65.12, S D=34.95)$, GSE3 $(n=962, M=58.02, \mathrm{SD}=35.42)$, GSE4 $(n=2226, M=45.95, S D=36.17)$, unknown $(n=245, M=37.84, \mathrm{SD}=37.47)$ and A/T/VSE $(n=452, M=23.69, S D=31.18)$. The post hoc analysis showed that all groups differed significantly. The mean CCR of the four prior achievement categories also differed significantly (Welch's $F(3,440.40)=316.09, p<.001)$ with a relatively high effect size $\left(\eta^{2}=0.126\right)$ : 'less than 60\%' $(n=99, M=19.16, S D=23.49)$, '60\%69\%' $(n=2240, M=39.91, S D=35.04),{ }^{\prime} 70 \%-79 \%$ ' $(n=2721, M=60.82, S D=36.12)$ and ' $80 \%$ and more' $(n=485, M=78.85, S D=32.53)$. The Games-Howell post-hoc analysis showed that all groups differed significantly. Tables 7 and 8 show the results of the multiple regression analysis.

Table 7. 
Table 8.

As can be seen in the analyses the ARV screening test result explains $9.3 \%$ of variance in exam scores of the combined four cohorts. When personal background variables are added to the model, the change in $R^{2}$ is significant, but relatively small (4.4\%), with a small effect on the predictive value of the ARV screening test. Of the personal variables, SES is the strongest predictor. The predictive value of the remaining personal background variables is fairly small, and nationality is not significant as a predictor. When the educational background variables are added in Model 3, a significant and much larger change in $R^{2}$ can be noticed and the percentage of explained variance increases to $26.9 \%$. In this model, the predictive value of the ARV screening test diminishes substantially, with its standardized beta value changing from 0.274 in model 2 to 0.124 in Model 3. The predictive value of the personal background variables remains significant but weak, and nationality also becomes significant when controlling for educational background variables. In Model 3, SES remains the most important predictor of the personal background variables. When the ARV screening test score is left out of the third model, the explained variance drops by $1.3 \%$, showing that the language screening test is a significant, but very small contributor to the model when personal background factors and educational background factors are taken into account.

\section{Discussion}

In this study, the predictive validity of a practical screening test testing academic reading and vocabulary was investigated. Our results appear to confirm Hulstijn's hypothesis in that there is substantial variation in the ARV screening test results of mostly native speakers of Dutch when lexically, syntactically, and cognitively complex language typically found in higher education is tested (Hulstijn, 2015). Our study also shows that it is possible to screen large groups of incoming students in a practical way, 
i.e. quickly and without using too many resources for its administration and scoring. The practicality of the test, however, has its downsides in that it uses mostly indirect tasks and has only limited internal consistency, especially when time pressure increases. The similarity of the predictive relation across versions suggests that the time constraints should not be too strict, in order to reduce the negative effect of test speed on its internal consistency. Future efforts could also focus on establishing a longer version of the ARV screening test, thereby increasing internal consistency.

The first research question in this study was whether the ARV screening test scores correlated with academic achievement. Our findings are consistent with the results in the literature on the predictive validity of language tests with a significant, but modest correlation coefficient of around .30 (Cotton \& Conrow, 1998; Criper \& Davies, 1998; Davies, 2007; De Wachter, Heeren, Marx \& Huyghe, 2013; Elder, 1993; Elder, 2017; Feast, 2002; Ferguson \& White, 1993; Graham, 1987; Hill, Storch, \& Lynch. 1999; Kerstjens \& Nery, 2000; Vinke \& Jochems, 1993; Read, 2015; Read, 2016; Van Dyk, 2015). Language proficiency is generally seen as a significant but weak predictor since other factors, academic and non-academic, such as intelligence, personality, attitude and even health contribute to academic success (Davies, 2007; Graham, 1987). The correlation coefficient also remains relatively stable during the first year.

The second research question investigated whether the ARV screening test manages to identify an at-risk group of students. Our analyses confirm that while the correlation with achievement is linear, the ARV screening test score is most meaningful at the lower end of the scale, especially in the first exam period in January. Students obtaining a low score on the ARV screening test have a higher risk of obtaining a low CCR (De Wachter, Heeren, Marx \& Huyghe, 2013; Elder, Bright \& Bennet, 2007; Van Dyk, 2015). As Davies (2007) points out, language proficiency seems to be necessary 
but not sufficient for study success: the higher a student's language proficiency, the more other factors come into play. Students scoring below a certain language proficiency threshold, however, are clearly more at risk. This effect seems to be more pronounced in January, since a number of students in all ARV screening test score groups improved during the first year. Future research could look further into the role of non-cognitive factors such as motivation and students' attitudes towards learning, especially regarding the academic performance of the lowest scoring language screening test groups.

To answer the third research question, the ARV screening test results were controlled for personal and educational background variables. The personal background variables used in this study ('gender', 'age', 'SES', 'nationality' and 'home language') appear to have a rather small effect on the predictive value of the screening test score. Educational background variables, on the other hand, do seem to have a considerable impact. When controlling for these background variables in a regression model, the additional predictive value of the screening test score becomes very small. These results align with the findings of Hamilton et al. (1993) and Stricker (2004) in that our measure of academic reading and vocabulary in a sample of mainly native speakers mostly reflects prior educational attainments, which, being a set of complex variables in itself, might also be partly an effect of language skills. Our results also highlight the complexity of the academic achievement variable. Even when controlled for personal background variables, educational background variables, and academic language proficiency, the model still only accounts for $26.9 \%$ of the variance in CCR, meaning that $73.1 \%$ is left unexplained. 


\section{Conclusion}

In response to the relatively large group of starting students, a practical, low-stakes web-based ARV screening test was implemented in several faculties at KU Leuven. The practicality of the screening test has led to a relatively large uptake, with over a thousand students in different faculties participating each academic year. That same practicality, however, also comes with its downsides, which has an impact on the possible uses of the screening test. These uses relate directly to the notion of validity and more specifically the claims that can be made based on the test results. Validity does not only pertain the instrument itself, but also includes the inferences that can be made, as well as the consequences and actions taken, based on test scores (Bachman \& Palmer, 2010; Kane, 2013; Messick, 1989). In the case of the ARV screening test, this means that in its low stakes use, it is clearly a useful instrument for detecting at-risk students and possibly advising them remedial courses or further diagnostic testing. However, the screening test can never be used when the stakes are any higher. Its predictive value is too small and the screening test, however practical, is not extensive enough to adequately generalize to interpretations about the whole domain of academic language proficiency to be used for high-stakes testing.

The predictive value of the ARV screening test does not change much when controlled for personal variables, but it is reduced substantially when educational background variables are added to the regression model. This suggests that the variance in achievement explained by ARV screening test overlaps strongly with the amount of variance explained by educational variables and that, although the ARV screening test offers a significant contribution to these variables in a regression model, its contribution is very small. Our results indicate that in populations of mostly native speakers academic language proficiency mainly reflects prior educational accomplishments. 
The ARV screening test, with its low-stakes use in an open university system such as in Flanders, can be considered to have predictive validity, since the evidence indicates that it contains valuable information about future performance. More specifically, although it is not a very strong predictor of academic achievement, it can detect students potentially at risk of academic failure. As Ferguson and White (1993) suggest, a more appropriate term than 'predictive validity' might be 'predictive utility'. In all, the ARV screening test is useful as an early-alert signal prompting faculties and students themselves to further diagnose the specific linguistic domains in which they need support or remedial courses.

\section{Declaration of interest statement}

No potential conflict of interest was reported by the authors.

\section{References}

Alderson, J. C. 2000. Assessing Reading. Cambridge: Cambridge University Press. Bachman, L., and A. Palmer. 1996. Language Testing in Practice: Designing and Developing Useful Language Tests. Oxford: Oxford University Press.

Bachman, L., and A. Palmer. 2010. Language Assessment in Practice. Oxford: Oxford University Press.

Baker, C., and W.E. Wright. 2017. Foundations of Bilingual Education and Bilingualism. $6^{\text {th }}$ ed. Bristol: Multilingual Matters.

Berckmoes, D. and H. Rombouts. 2009. Intern rapport verkennend onderzoek naar knelpunten taalvaardigheid in het hoger onderwijs. [Internal report of an explorative study on language stumbling blocks in higher education]. Antwerpen: Universiteit Antwerpen.

http://uahost.uantwerpen.be/linguapolis/mom/Intern_rapport_verkennend_onder zoek_naar_knelpunten_taalvaardigheid_in_het_hoger_onderwijsMonitoraat_op_maat.pdf

Cotton, F., and F. Conrow. 1998. "An Investigation of the Predictive Validity of IELTS amongst a Group of International Students Studying at the University of 
Tasmania." Vol. 1 of the IELTS Research Reports. Sydney: ELICOS

Association Limited

Criper, C., and A. Davies. 1988. ELTS Validation Project Report: ELTS Research Report 1 (I). Cambridge: The British Council and University of Cambridge Local Examinations Syndicate.

Crossman, K. 2018. "Immersed in Academic English: Vocabulary and Academic Outcomes of a CLIL University Preparation Course.” International Journal of Bilingual Education and Bilingualism 21 (5): 564-577.

Davies, A. 2001. “The Logic of Testing Languages for Specific Purposes.” Language Testing 18 (2): 137-147.

Davies, A. 2007. “Assessing Academic English Language Proficiency: 40+ Years of U.K. Language Tests.” In Language Testing Reconsidered, edited by J. Fox, M. Wesche, D. Bayliss, L. Cheng, C. E. Turner and C. Doe, 73-86. Ontario: University of Ottawa Press.

De Wachter, L., and L. Cuppens. 2010. "Detectie en remediëring van taalleerzorgproblemen voor eerstejaarsstudenten aan de K.U. Leuven.” [The detection and remediation of language problems of first-year students at the university of Leuven]. In 24ste conferentie het schoolvak Nederlands, edited by S. Vanhooren and A. Mottart, 260-264. Gent: Academia Press.

De Wachter, L., and J. Heeren. 2013. "Een taaltest als signaal: De ontwikkeling en implementatie van een strategische taalvaardigheidstoets aan de KU Leuven." [A language test as a signal: The development and implementation of a strategic language proficiency test at the KU Leuven]. Levende Talen Tijdschrift 14 (1): $19-27$.

De Wachter, L., J. Heeren, S. Marx, and S. Huyghe. 2013. “Taal: een noodzakelijke, maar niet de enige voorwaarde tot studiesucces: De correlatie tussen de resultaten van een taalvaardigheidstoets en de slaagcijfers bij eerstejaarsstudenten aan de KU Leuven.” [Language proficiency: A necessary, but not the only, condition for study success: A correlation between the results of a language proficiency test and academic achievement of first-year students]. Levende Talen Tijdschrift 14 (4): 28-36.

Department of Education and Training. 2008. Education in Flanders. A Broad View of the Flemish Educational Landscape. Brussels: Agency for Educational Communication. 
Declerq, K., and F. Verboven. 2010. Slaagkansen aan Vlaamse universiteiten: tijd om het beleid bij te sturen? [Success rates at Flemish universities: Time to adjust policy?]. Centrum voor economische studieën, KU Leuven. https://www.classicavlaanderen.be/informatie/cijfermateriaal/slaagkansen.pdf

Deygers, B., K. Van Den Branden, and E. Peters. 2017. "Checking Assumed Proficiency: Comparing L1 and L2 Performance on a University Entrance Test." Assessing Writing 32: 43-56. doi:10.1016/j.asw.2016.12.005.

Dooey, P., and R. Oliver. 2002. "An Investigation into the Predictive Validity of the IELTS Test as an Indicator of Future Academic Success." Prospect 7 (1): 36-54.

Douma, W.H. 1960. De leesbaarheid van landbouwbladen: een onderzoek naaren een toepassing van leesbaarheidsformules [The readabilityof agricultural journals: A study to and application of readability formulas]. Wageningen: Bulletin no. 17, afdeling Sociologie en Sociografie van de Landbouwhogeschool.

Elder, C. 1993. "Language Proficiency as a Predictor of Performance in Teacher Education." Melbourne Papers in Language Testing 2 (1): 68-85.

Elder, C. 2017. “Language Assessment in Higher Education.” Vol. 7 of the Encyclopedia of Language and Education, edited by E. Shohamy and N. Hornberger, 271-286. Netherlands: Springer. doi:10.1007/978-3-319-02261$1 \_35$.

Elder, C., C. Bright, and S. Bennet. 2007. "The Role of Language Proficiency in Academic Success: Perspectives from a New Zealand University." Melbourne Papers in Language Testing 12 (1): 24-58.

Elder, C., and J. von Randow. 2008. "Exploring the Utility of a Web-Based English Language Screening Tool.” Language Assessment Quarterly 5 (3): 173-194.

Feast, V. 2002. "The Impact of IELTS Scores on Performance at University." International Education Journal 13 (4): 70-85.

Ferguson, G., and E. White. 1993. "A Small-scale Study of Predictive Validity.” Melbourne papers in Language Testing 2 (1): 68-87.

Flesch, R. 1948. “A new readability yardstick.” Journal of Applied Psychology 32 (3): $221-233$.

Fløttum, K., D. Dahl, and T. Kinn. 2006. Academic Voices: Across Languages and Disciplines. Amsterdam: John Benjamins Publishing Company. 
Giezenaar, G., and E. Schouten, 2002. Wijze woorden. Woordenlijst academisch Nederlands met idioomoefeningen [Wise words. Wordlist academic Dutch with exercises]. Deurne: Intertaal.

Glorieux, I., I. Laurijssen, and O. Sobczyk. 2014. "De instroom in het hoger onderwijs in Vlaanderen: Een beschrijving van de huidige instroompopulatie en een analyse van de overgang van secundair onderwijs naar hoger onderwijs." [The inflow of first-year students in Flemish higher education: A description of the current first-year population and an analysis of the transition from secondary education into higher education]. Leuven: Steunpunt SSL.

Graham, J. G. 1987. "English Language Proficiency and the Prediction of Academic Success.” TESOL Quarterly 21 (3): 505-521. doi:10.2307/3586500

Hamilton, J., M. Lopes, T. McNamara, and E. Sherman. 1993. "Rating Scales and Native Speaker Performance on a Communicatively Oriented EAP Test.” Language Testing 10: 337-353. doi:10.1177/026553229301000307

Harrell, F.H. 2018. Hmisc: Harrell Miscellaneous. Version 4.1-1. https://CRAN.Rproject.org/package $=$ Hmisc

Hill, K., N. Storch, and B. Lynch. 1999. “A Comparison of IELTS and TOEFL as Predictors of Academic Success." In International English Language Testing System (IELTS) Research Reports, edited by R. Tulloh, 53-63. Canberra: IELTS Australia.

Hulstijn, J. 2015. Language Proficiency in Native and Non-native Speakers: Theory and Research. Amsterdam: John Benjamins Publishing Company.

Hyland, K. 2006. English for Academic Purposes: An Advanced Resource Book. London: Routledge

IBM Corp. 2016. IBM SPSS Statistics for Windows, Version 24.0. Armonk, NY: IBM Corp.

Kane, M., T. (2013). "Validating the Interpretations and Uses of Test Scores." Journal of Educational measurement 50 (1): 1-73.

Kerstjens, M., and C. Nery. 2000. "Predictive Validity in the IELTS Test: A Study of the Relationship between IELTS Scores and Students' Subsequent Academic Performance." Vol. 3 of the International English Language Testing System (IELTS) Research Reports, edited by R. Tulloh, 85-108. Melbourne: IELTS Australia, 2000. 
Knoch, U., and C. Elder. 2013. "A Framework for Validating Post-entry Language Assessments (PELAs)." Papers in Language Testing and Assessment 2 (2): 4866

KU Leuven. 2018. Cumulative Study Efficiency (CSE). https://www.kuleuven.be/english/education/student/studyprogress/cse $20 / 08 / 2018$

Lacante, M., M. De Metsenaere, W. Lens, R. Van Esbroeck, K. De Jaeger, T. De Conick, K. Gressens, et al. 2001. Drop-out in het hoger onderwijs: Onderzoek naar de achtergronden en motieven van drop-out in het eerste jaar hoger onderwijs. [Drop-out in higher education: Research into the backgrounds and motives of drop-out in higher education]. Brussels: Vrije Universiteit Brussel.

McNamara, T., and K. Ryan. 2011. "Fairness versus Justice in Language Testing: The Place of English Literacy in the Australian Citizenship Test." Language Assessment Quarterly 8 (2): 161-178.

Messick, S. 1989. "Validity.” In Educational Measurement, edited by R. L. Linn, 13103. New York: Macmillan.

Milton, J., and J. Treffers-Daller. 2013. "Vocabulary Size Revisited: The Link between Vocabulary Size and Academic Achievement." Applied Linguistic Review 4: 151-172. doi:10.1515/applirev-2013-0007.

Pinxten, M., B. De Fraine, W. Van Den Noortgate, J. Van Damme, T. Boonen, and G. Vanlaar. 2014. “'I Choose so I Am': A Logistic Analysis of Major Selection in University and Successful Completion of the First Year." Studies in Higher Education. doi:10.1080/03075079.2014.914904

Pinxten, M., C. Van Soom, C. Peeters, T. De Laet, and G. Langie. 2017. "At-risk at the Gate: Prediction of Study Success of First-Year Science and Engineering Students in an Open-Admission University in Flanders - any Incremental Validity of Study Strategies?” European Journal of Psychology of Education, 34 (1): 45-66.

Qian, D. D. 2002. “Investigating the Relationship between Vocabulary Knowledge and Academic Reading Performance: an Assessment Perspective." Language Learning 52 (3): 513-536. doi:10.1111/1467-9922.00193

Read, J. 2015. Assessing English Proficiency for University Study. New York: Palgrave, Macmillan. 
Read, J. 2016. "Some Key Issues in Post-Admission Language Assessment.” In Postadmission Language Assessment. edited by J. Read, 3-20. Switzerland: Springer.

Revelle, W. 2018. psych: Procedures for Personality and Psychological Research.

Version 1.8.4. Evanston: Northwestern University. https://CRAN.Rproject.org/package $=$ psych

Richardson M., C. Abraham, and R. Bond. 2012. "Psychological Correlates of University Students' Academic Performance: a Systematic Review and Metaanalysis." Psychological Bulletin 138 (2): 353-387.

Rombaut, K., B. Cantillon, and G. Verbist. 2006. "Determinanten van de differentiële slaagkansen in het hoger onderwijs." [Determinants of differential success rates in higher education]. Antwerpen: Universiteit Antwerpen.

Snow, C. E. 2010. “Academic Language and the Challenge of Reading for Learning about Science.” Science 328: 450-452. doi:10.1126/science.1182597.

Stricker, L. J. 2004. "The Performance of Native Speakers of English and ESL Speakers on the Computer-based TOEFL and GRE General Test.” Language Testing 21 (2): 146-173. doi:10.1191/0265532204lt279oa

Ting, S. R., and T. L. Robinson. 1998. "First-year Academic Success: A Prediction Combining Cognitive and Psychosocial Variables for Caucasian and African American Students.” Journal of College Student Development 39 (6): 599-610.

Van den Branden, K. 2010. "Taalbeleid in het hoger onderwijs." [Language policy in higher education]. In Taalbeleid in het hoger onderwijs: de hype voorbij? edited by E. Peters en T. Van Houtven, 213-223. Leuven: Acco.

Van Dyk, T. 2015. "Tried and Tested: Academic Literacy tests as Predictors of Academic Success.” Tijdschrift voor Taalbeheersing 37 (2): 159-186. doi:10.5117/tvt2015.2.vand

van Kalsbeek, A., and F. Kuiken. 2014. "Academisch taalgebruik in het Nederlandse wetenschappelijk onderwijs: stand van zaken en blik op de toekomst." [Academic language use in scientific education in the Netherlands: State of affairs and a look into the future]. Internationale Neerlandistiek 52 (3): 221-236.

Van Houtven, T., E., Peters, and Z. El Morabit. 2010. "Hoe staat het met de taal van studenten? Exploratieve studie naar begrijpend lezen en samenvatten bij instromende studenten in het Vlaamse hoger onderwijs." [What is the state of students' language proficiency? An explorative study into the reading 
comprehension and summarizing skills of starting first-year students in Flemish higher education]. Levende Talen Tijdschrift 11 (3): 29-44.

Van Houtven, T., E. Peters, and K. Van den Branden. 2013. “Analyzing Student Teachers' Academic Literacy Needs: a Qualitative Analysis of Flemish Firstyear Teacher Trainees' Needs." Language Learning in Higher Education 2 (2): 267-292.

Van Soom, C., and V. Donche. 2014. "Profiling First-Year Students in STEM Programs Based on Autonomous Motivation and Academic Self-Concept and Relations with Academic Achievement." PLoS One 9: 1-13. doi:10.1371/journal.pone.0112489.

Verlinde, S., and G. Peeters. 2012. "Data Access Revisited: The Interactive Language Toolbox.” In Electronic Lexicography, edited by S. Granger and M. Paquot. Oxford: Oxford university press. doi:10.1093/acprof:oso/9780199654864.003.0008

Vinke, A. A., and W. M. G. Jochems. 1993. "English Proficiency and Academic Success in International Postgraduate Education." Higher Education 26 (3): 275-285.

Weir, C. J. 2005. Language Testing and Validation: An Evidence-based Approach. New York: Palgrave MacMillan.

Wingate, U. 2015. Academic Literacy and Student Diversity: The Case for Inclusive Practice. Bristol: Multilingual Matters. 
Table 1. Item types, item formats and tasks used in the ARV screening test.

\begin{tabular}{|c|c|c|}
\hline Item type & Item format & Tasks \\
\hline $\begin{array}{l}\text { 1. Find the correct } \\
\text { synonym for a word in } \\
\text { a sentence }\end{array}$ & $\begin{array}{l}\text { multiple choice ( } 4 \\
\text { options) }\end{array}$ & $\begin{array}{l}\text { - understanding academic vocabulary in a } \\
\text { sentence }\end{array}$ \\
\hline $\begin{array}{l}\text { 2. Select the correct } \\
\text { word for a blank in a } \\
\text { text }\end{array}$ & $\begin{array}{l}\text { multiple choice ( } 4 \\
\text { options) }\end{array}$ & $\begin{array}{l}\text { - understanding academic vocabulary beyond } \\
\text { the sentence level }\end{array}$ \\
\hline $\begin{array}{l}\text { 3. Select } 1 \text { word for } 3 \\
\text { given contexts }\end{array}$ & $\begin{array}{l}\text { multiple choice (7-9 } \\
\text { options) }\end{array}$ & $\begin{array}{l}\text { - understanding academic vocabulary in a } \\
\text { sentence }\end{array}$ \\
\hline 4. Word formation & $\begin{array}{l}\text { completion/fill-in- } \\
\text { the-blank }\end{array}$ & $\begin{array}{l}\text { - understanding academic vocabulary in a } \\
\text { sentence } \\
\text { - deriving and producing different grammatical } \\
\text { forms of a word }\end{array}$ \\
\hline 5. Scrambled text & $\begin{array}{l}\text { drag and drop } \\
\text { sentences }\end{array}$ & $\begin{array}{l}\text { - understanding relations between sentences } \\
\text { - understanding rhetorical patterns } \\
\text { - making meaning of a text beyond the } \\
\text { sentence level }\end{array}$ \\
\hline $\begin{array}{l}\text { 6. Reading for } \\
\text { structure }\end{array}$ & multiple choice & $\begin{array}{l}\text { - understanding relations between sentences } \\
\text { - understanding rhetorical patterns } \\
\text { - making meaning of a text beyond the } \\
\text { sentence level }\end{array}$ \\
\hline $\begin{array}{l}\text { 7. Reading } \\
\text { comprehension }\end{array}$ & multiple choice & $\begin{array}{l}\text { - making meaning of a text beyond the } \\
\text { sentence level } \\
\text { - understanding the essence of a complex text }\end{array}$ \\
\hline 8. Connectors & $\begin{array}{l}\text { completion/fill-in- } \\
\text { the-blank }\end{array}$ & $\begin{array}{l}\text { - understanding relations between sentences } \\
\text { - using connectors to link ideas }\end{array}$ \\
\hline 9. Punctuation & $\begin{array}{l}\text { completion/fill-in- } \\
\text { the-blank }\end{array}$ & - using punctuation correctly \\
\hline
\end{tabular}


Table 2. Overview of item types per test version.

\begin{tabular}{lllllllllll}
\multicolumn{1}{c}{} & \multicolumn{1}{c}{ Item type } & \multicolumn{1}{c}{ Total items } \\
\cline { 1 - 7 } Academic year & 1 & 2 & 3 & 4 & 5 & 6 & 7 & 8 & 9 & \\
& & & & & & & & & & \\
\hline $2010-2013-2014$ & 4 & 4 & 4 & 7 & 1 & 3 & 2 & 0 & 0 & 25 \\
2011 & 4 & 4 & 4 & 7 & 1 & 3 & 2 & 3 & 3 & 31 \\
2012 & 4 & 8 & 4 & 7 & 2 & 3 & 3 & 0 & 0 & 31 \\
2015 & 4 & 5 & 4 & 7 & 2 & 3 & 3 & 0 & 0 & 28 \\
$2016-2017$ & 4 & 5 & 3 & 6 & 2 & 3 & 3 & 0 & 0 & 26 \\
\hline
\end{tabular}


Table 3. Test version, descriptive data, number of time-outs and reliability measures per academic year.

\begin{tabular}{lrlrrrrc}
\hline Year & $\begin{array}{c}\text { Test } \\
\text { version }\end{array}$ & N & Mean (\%) & $S D$ & $\begin{array}{c}\text { \% of } \\
\text { time-outs }\end{array}$ & $\begin{array}{r}\text { Cronbach's } \\
\alpha\end{array}$ & Test-retest \\
\hline 2010 & 1.1 & 1291 & 64.7 & 14.61 & $3 \%$ & .69 & $.75(\mathrm{n}=15)$ \\
2011 & 1.2 & 1521 & 67.3 & 12.97 & $7 \%$ & .65 & $/$ \\
2012 & 2 & 2380 & 71.3 & 12.90 & $29 \%$ & .63 & $/$ \\
2013 & 1.1 & 1641 & 67.0 & 14.36 & $4 \%$ & .68 & $/$ \\
2014 & 1.1 & 1972 & 66.2 & 14.86 & $6 \%$ & .70 & $/$ \\
2015 & 3.1 & 1237 & 69.1 & 13.33 & $20 \%$ & .59 & $.77(\mathrm{n}=30)$ \\
2016 & 3.2 & 1140 & 66.5 & 14.13 & $19 \%$ & .62 & $.74(\mathrm{n}=30)$ \\
2017 & 3.2 & 1465 & 67.2 & 14.45 & $16 \%$ & .64 & $/$ \\
\hline
\end{tabular}


Table 4. Overview of the number of students and their faculties in the dataset for the predictive validity analysis that participated in the ARV screening test.

\begin{tabular}{llllllllll}
\hline Faculty & 2010 & 2011 & 2012 & 2013 & 2014 & 2015 & 2016 & 2017 & Total \\
\hline Economics & 643 & & 529 & & & & & 101 & 1273 \\
Social Sciences & 198 & 301 & 219 & 233 & 213 & 212 & 225 & 243 & 1844 \\
Arts & 163 & 275 & 267 & 317 & 224 & 212 & 254 & 375 & 2087 \\
Psychology and Pedagogy & & & 511 & & 393 & & & & 904 \\
Law & & 597 & 459 & 738 & 783 & 770 & 645 & 728 & 4720 \\
Sciences & 274 & 335 & 356 & 310 & 332 & & & & 1607 \\
\hline Total & 1278 & 1508 & 2341 & 1598 & 1945 & 1194 & 1124 & 1447 & 12,435 \\
\hline
\end{tabular}


Table 5. Spearman's rank correlation between the ARV screening test score and students' CCR in January, CCR in June and CCR at the end of the first year per academic year (all correlations are significant at the $p<0.001-$ level).

\begin{tabular}{lllllll} 
& $\begin{array}{l}\text { CCR } \\
\text { January }\end{array}$ & & $\begin{array}{l}\text { CCR } \\
\text { June }\end{array}$ & \multicolumn{3}{l}{$\begin{array}{l}\text { CCR } \\
\text { year 1 }\end{array}$} \\
\hline Year & Spearman & $\mathrm{n}$ & Spearman & $\mathrm{n}$ & Spearman & $\mathrm{n}$ \\
\hline 2010 & .34 & 1250 & .35 & 1244 & .33 & 1258 \\
2011 & .32 & 1474 & .38 & 1468 & .36 & 1475 \\
2012 & .27 & 2267 & .27 & 2261 & .25 & 2274 \\
2013 & .29 & 1555 & .31 & 1548 & .29 & 1556 \\
2014 & .34 & 1871 & .35 & 1863 & .32 & 1879 \\
2015 & .34 & 1161 & .34 & 1159 & .32 & 1167 \\
2016 & .30 & 1096 & .31 & 1083 & .31 & 1099 \\
2017 & .30 & 1397 & .33 & 1395 & .34 & 1402 \\
\hline
\end{tabular}


Table 6. Spearman's rank correlation of ARV screening test scores and CCR at the end of the first year per faculty (n).

\begin{tabular}{|c|c|c|c|c|c|c|c|c|c|}
\hline Faculty & 2010 & 2011 & 2012 & 2013 & 2014 & 2015 & 2016 & 2017 & Total \\
\hline Economics & $\begin{array}{l}.32 * * * \\
(633)\end{array}$ & & $\begin{array}{l}.29 * * \\
* \\
(518)\end{array}$ & & & & & $\begin{array}{l}.27 * * \\
(100)\end{array}$ & $\begin{array}{l}.29 * * * \\
(1251)\end{array}$ \\
\hline $\begin{array}{l}\text { Social } \\
\text { Sciences }\end{array}$ & $\begin{array}{l}.31 * * * \\
(195)\end{array}$ & $\begin{array}{l}.42^{* *} \\
* \\
(294)\end{array}$ & $\begin{array}{l}.35^{* *} \\
* \\
(215)\end{array}$ & $\begin{array}{l}.34 * * \\
* \\
(229)\end{array}$ & $\begin{array}{l}.23 * * \\
(208)\end{array}$ & $\begin{array}{l}.37^{* *} \\
* \\
(208)\end{array}$ & $\begin{array}{l}.15^{*} \\
(220)\end{array}$ & $\begin{array}{l}.26^{* *} \\
* \\
(231)\end{array}$ & $\begin{array}{l}.29 * * * \\
(1800)\end{array}$ \\
\hline Arts & $\begin{array}{l}.33 * * * \\
(159)\end{array}$ & $\begin{array}{l}.38 * * \\
* \\
(269)\end{array}$ & $\begin{array}{l}.23 * * \\
* \\
(256)\end{array}$ & $\begin{array}{l}.29 * * \\
* \\
(311)\end{array}$ & $\begin{array}{l}.37 * * \\
* \\
(214)\end{array}$ & $\begin{array}{l}.28 * * \\
* \\
(209)\end{array}$ & $\begin{array}{l}.40 * * * \\
(245)\end{array}$ & $\begin{array}{l}.42 * * \\
* \\
(361)\end{array}$ & $\begin{array}{l}.34 * * * \\
(2025)\end{array}$ \\
\hline $\begin{array}{l}\text { Psychology } \\
\text { and Pedagogy }\end{array}$ & & & $\begin{array}{l}.26^{* *} \\
* \\
(498)\end{array}$ & & $\begin{array}{l}.32 * * \\
* \\
(382)\end{array}$ & & & & $\begin{array}{l}.28 * * * \\
(880)\end{array}$ \\
\hline Law & & $\begin{array}{l}.39 * * \\
* \\
(586)\end{array}$ & $\begin{array}{l}.31^{* *} \\
* \\
(453)\end{array}$ & $\begin{array}{l}.28^{* *} \\
* \\
(723)\end{array}$ & $\begin{array}{l}.33 * * \\
* \\
(765)\end{array}$ & $\begin{array}{l}.31^{* *} \\
* \\
(750)\end{array}$ & $\begin{array}{l}.32 * * * \\
(634)\end{array}$ & $\begin{array}{l}.33^{* *} \\
* \\
(710)\end{array}$ & $\begin{array}{l}.31 * * * \\
(4622)\end{array}$ \\
\hline Sciences & $\begin{array}{l}.38 * * * \\
(271)\end{array}$ & $\begin{array}{l}.22 * * \\
* \\
(326)\end{array}$ & $\begin{array}{l}.19 * * \\
(334)\end{array}$ & $\begin{array}{l}.25^{* *} \\
* \\
(293)\end{array}$ & $\begin{array}{l}.30 * * \\
* \\
(310)\end{array}$ & & & & $\begin{array}{l}.25 * * * \\
(1534)\end{array}$ \\
\hline
\end{tabular}

$* p<0.05, * * p<0.01, * * * p<0.001$ 
Table 7. Regression models for the ARV screening test scores of 2014-2015, 20152016, 2016-2017 and 2017-2018 cohorts with CCR at the end of the first year as dependent variable.

\begin{tabular}{|c|c|c|c|c|c|c|}
\hline \multirow{2}{*}{ Model } & & \multicolumn{2}{|c|}{$\begin{array}{l}\text { Unstandardized } \\
\text { coefficients }\end{array}$} & \multirow{2}{*}{$\begin{array}{l}\text { Standardized } \\
\text { coefficients } \\
\beta \beta\end{array}$} & \multirow[b]{2}{*}{$t$} & \multirow[b]{2}{*}{ Sig. } \\
\hline & & $B$ & $S E B$ & & & \\
\hline \multirow[t]{3}{*}{1} & $R^{2}=.093$ & & & & & \\
\hline & Constant & -1.404 & 2.471 & & -0.568 & 0.570 \\
\hline & ARV screening test & 0.822 & 0.036 & .305 & 23.007 & $<0.001$ \\
\hline \multirow[t]{8}{*}{2} & $R^{2}=.137$ & & & & & \\
\hline & Constant & 30.497 & 12.264 & & 2.487 & 0.013 \\
\hline & ARV screening test & 0.737 & 0.036 & .274 & 20.330 & $<0.001$ \\
\hline & Age & -3.674 & 0.570 & -.087 & -6.446 & $<0.001$ \\
\hline & Gender & 7.540 & 1.028 & .096 & 7.338 & $<0.001$ \\
\hline & SES & 6.776 & 0.632 & .141 & 10.713 & $<0.001$ \\
\hline & Nationality & 0.517 & 2.795 & .002 & 0.185 & 0.853 \\
\hline & Home language & -7.566 & 1.506 & -.067 & -5.023 & $<0.001$ \\
\hline \multirow[t]{10}{*}{3} & $R^{2}=.269$ & & & & & \\
\hline & Constant & 28.080 & 11.354 & & 2.473 & 0.013 \\
\hline & ARV screening test & 0.335 & 0.036 & .124 & 9.327 & $<0.001$ \\
\hline & Age & -1.981 & 0.534 & -.047 & -3.713 & 0.003 \\
\hline & Gender & 5.205 & 0.954 & .066 & 5.457 & $<0.001$ \\
\hline & SES & 4.721 & 0.592 & .098 & 7.980 & $<0.001$ \\
\hline & Nationality & -6.331 & 2.588 & -.030 & -2.446 & 0.014 \\
\hline & Home language & -7.409 & 1.387 & -.065 & -5.340 & $<0.001$ \\
\hline & SE Track & -7.146 & 0.360 & -.264 & -19.827 & $<0.001$ \\
\hline & Mean \% SE & 15.554 & 0.704 & .274 & 22.080 & $<0.001$ \\
\hline \multirow[t]{9}{*}{4} & $R^{2}=.256$ & & & & & \\
\hline & Constant & 55.060 & 11.071 & & 4.973 & $<0.001$ \\
\hline & Age & -2.264 & 0.537 & -.053 & -4.214 & $<0.001$ \\
\hline & Gender & 3.874 & 0.951 & .049 & 4.073 & $<0.001$ \\
\hline & SES & 5.154 & 0.595 & .107 & 8.667 & $<0.001$ \\
\hline & Nationality & -5.945 & 2.609 & -.028 & -2.279 & 0.023 \\
\hline & Home language & -8.813 & 1.391 & -.078 & -6.337 & $<0.001$ \\
\hline & SE Track & -8.074 & 0.349 & -.298 & -23.113 & $<0.001$ \\
\hline & Mean \% SE & 17.082 & 0.691 & .301 & 24.728 & $<0.001$ \\
\hline
\end{tabular}


Table 8. Anova table.

\begin{tabular}{lllllll}
\hline Model & & Sum of Squares & df & Mean Square & $F$ & Sig. \\
\hline 1 & Regression & 673937.053 & 1 & 673937.053 & 529.324 & $<0.001$ \\
& Residual & 6573545.245 & 5163 & 1273.203 & & \\
& Total & 7247482.297 & 5164 & & & \\
2 & Regression & 992664.631 & 6 & 165444.105 & 136.433 & $<0.001$ \\
& Residual & 6254817.666 & 5158 & 1212.644 & & \\
& Total & 7247482.297 & 5164 & & & \\
3 & Regression & 1946477.284 & 8 & 243309.661 & 236.654 & $<0.001$ \\
& Residual & 5301005.013 & 5156 & 1028.124 & & \\
4 & Total & 7247482.297 & 5164 & & & \\
4 & Regression & 1857030.610 & 7 & 265290.087 & 253.801 & $<0.001$ \\
& Residual & 5390451.687 & 5157 & 1045.269 & & \\
& Total & 7247482.297 & 5164 & & & \\
\hline
\end{tabular}


Figure 1. Relation between ARV screening test score and CCR in January.

Figure 2. Relation between ARV screening test score and CCR at the end of the first year. 